\title{
Assessment of interactions between defoliation and Phytophthora plurivora stem infections of birch seedlings
}

\author{
by Tomasz Oszako ${ }^{1}$ Dzmitry Voitka², Miłosz Tkaczyk¹, Nenad Keča ${ }^{3}$, Lassaâd Belbahrii and Justyna A. Nowakowska ${ }^{5}$
}

\begin{abstract}
Silver birch, (Betula pendula), is an important forest tree species in Poland used for afforestation in rural areas and planted in wet forest types to ameliorate excess water. Physiological stress may increase susceptibility of trees to disease and it is hypothesized that insect defoliation can predispose birch to Phytophthora plurivora infection. In order to evaluate the effect of defoliation stress and phytophthora infection, removal of all (100\%) or partial (50\%) foliage from one-year-old $B$. pendula seedlings simulating insect damage was carried out in the greenhouse. Inoculation with $P$. plurivora mycelium at the base of the stem was performed by cutting the bark tissue 5-7 $\mathrm{cm}$ above the soil. Stem damage was assessed after 70 days in 2016 and after 365 days (at the end of the next growing season in September 2017) by measuring lesions sizes. We found that $B$. pendula can serve as a host of the soil-borne pathogen $P$. plurivora which causes mortality of birch seedlings in Polish nurseries. The results also show the statistically significant differences in lesion widths developed on stems after inoculation of both $50 \%$ and $100 \%$ defoliation treatments. Additionally, defoliation significantly reduced root development.
\end{abstract}

Key words: Betula pendula, Phytophthora plurivora, necrosis, decline, pathogenicity

\begin{abstract}
RÉSUMÉ
Le bouleau verruqueux (Betula pendula) est une essence forestière importante en Pologne; elle est utilisée pour le boisement des terres agricoles et pour le reboisement des forêts sur sols humides afin d'en contrôler l'excès d'eau. Le stress physiologique pourrait accroître la susceptibilité des arbres aux maladies et nous avons fait l'hypothèse que la défoliation par les insectes prédisposerait les bouleaux à l'infection par le Phytophthora plurivora. Afin dévaluer l'effet du stress causé par la défoliation, nous avons enlevé la totalité (100\%) ou une partie $(50 \%)$ du feuillage sur des semis d'un an de $B$. Pendula en serre afin de simuler une défoliation par des insectes. Nous avons ensuite inoculé du mycélium de P. Plurivora à chaque tige après avoir fait une incision dans les tissus de l'écorce à 5-7 cm au-dessus du sol. Lévaluation des dommages 70 jours plus tard, en 2016, et après 365 jours (à la fin de la saison de croissance suivante, en septembre 2017) en mesurant la taille des lésions. Nous avons constaté alors que B. Pendula peut être l'hôte de P. Plurivora, un agent pathogène du sol qui tue les semis de bouleau dans les pépinières de Pologne. Les résultats ont aussi révélé des différences significatives dans la largeur des lésions qui sétaient développées après inoculation des tiges, tant dans le traitement de défoliation à $50 \%$ que dans celui à $100 \%$. De plus, la défoliation a diminué de façon significative la croissance racinaire.
\end{abstract}

Mots-clés : Betula pendula, Phytophthora plurivora, nécrose, dépérissement, pathogénicité

\section{Introduction}

Silver birch (Betula pendula Roth) covers $5.7 \%$ of the land area in Poland and plays an important role as a pioneer species, especially on post-agricultural lands prior to Scots pine (Pinus sylvestris L.) plantation establishment. In the 1980s, severe birch dieback was observed in different parts of the country and this was often associated with the presence of Phytophthora citricola Sawada (now Phytophthora plurivora T. Jung and T.I. Burgess) (Oszako 2005). This species is one of the most common pathogens of fine roots of many deciduous species such as beech, oak, and ash, and often found in forest ecosystems, nurseries, and plantations (Rytkönen et al. 2012). Environmental stress may increase susceptibility to pathogens and it is hypothesized that insect damage may predispose birch to $P$. plurivora infections (Johnson et al. 2003). Leaves of birch are eaten by many insects belonging to Geometridae, especially Operophtera brumata L. Defoliation can result in physiological and biochemical changes in the wood (Sanz et al. 2012).

The aim of this study was to understand the interactions between partial and total defoliation stress to birch, and the impact of the soil-borne pathogen P. plurivora.

\footnotetext{
${ }^{1}$ Department of Forest Protection, Forest Research Institute, Braci Leśnej 3, Sękocin Stary 05-090, Poland, t.oszako@ibles.waw.pl

${ }^{2}$ Institute of Plant Protection, 2 Mira Street, Priluki BY-223011, Minsk District, Republic of Belarus

${ }^{3}$ Univeristy of Belgrade-Faculty of Forestry, Kneza Višeslava 1, 11030 Belgrade, Serbia

${ }^{4}$ Laboratory of Soil Biology, University of Neuchâtel, Rue Emile Argand 11, 2009 Neuchâtel, Switzerland

${ }^{5}$ Cardinal Stefan Wyszynski University in Warsaw, Faculty of Biology and Environmental Sciences, Wóycickiego 1/3 Street, 01-938

Warsaw, Poland
} 


\section{Materials and methods}

The variants of the experiment were:

Treatment 1: P. plurivora $+0 \%$ defoliation

Treatment 2: P. plurivora $+50 \%$ defoliation

Treatment 3: P. plurivora $+100 \%$ defoliation

Control: non-defoliated and inoculated with sterile media

To evaluate the effect of stress and infection of $B$. pendula (one-year-old seedlings) with P. plurivora NCBI KX618501, removal of all (100\%) or partial (50\%) foliage was carried out to simulate insect damage. Ten non-defoliated seedlings inoculated with $P$. plurivora and 10 seedlings inoculated only with a sterile plug of media served as check treatments. All seedlings were randomly chosen for treatment application and were visually homogenous in size and appearance. $P$. plurivora inoculum was produced by growing the oomycete on potato dextrose agar (Difco ${ }^{\text {tw }} \mathrm{PDA}$ ) for seven days at $25^{\circ} \mathrm{C}$ under laboratory conditions. One day after defoliation (partial or total), 10 plants of each group were inoculated with $P$. plurivora (Fig. 1). Inoculation was done by cutting the bark tissue $5-7 \mathrm{~cm}$ above the soil to expose the cambium, and inserting a 5-mm-diameter plug of $P$. plurivora-colonized PDA. The level of necrosis was assessed after 70 days by measuring the dimensions of lesions, and the differences among treatments was evaluated with the Kruskal-Wallis Test using the statistical software Statistica ver. 13 (StatSoft, CA, USA).

To fulfil Koch's postulates, 60 tissue samples from the margins of lesions of 15 seedlings (five of each of three treatments) were tested using a quantitative PCR assay (Table 1; Fig. 2). The remaining 15 plants inoculated with $P$. plurivora were kept for further observation of lesion development and plant mortality in the 2017 growing season. Sampling and isolation of $P$. plurivora were collected from the inoculation place and margins of symptomatic parts of the stems. Samples 3-4 $\mathrm{mm}$ were taken from the transition zone between necrotic and healthy phloem tissues. Tissue surface sterilization was with $1 \%$ sodium hypochlorite with $4 \%$ active hypochlorite for three minutes. Samples were washed three times in distilled water and plated onto selective agar media (V8-PARPNH) (Jung et al. 1996). Samples of wood from controls as well as from the group inoculated with $P$. plurivora, were also plated onto selective agar media. After the appearance of the first hyphae, they were transferred onto fresh MEA medium and incubated at $20^{\circ} \mathrm{C}$ in the dark. Morphological classification of isolates was performed according to Milenkovic et al. 2012 under the light microscope ZEISS Axioskop 2, equipped with Nikon Ds-fil camera, and NIS Elements AR4 $4^{\circ}$ software.

DNA was extracted using the NucleoSpin Plant II Kit (Macherey-Nagel, Germany) according to manufacturer's instructions. Real-time PCR was performed in a total volume of $20 \mu \mathrm{l}$ containing $20-50 \mathrm{ng}$ genomic DNA, $1 \times$ LuminoCt Master Mix (Sigma-Aldrich), $0.5 \mu$ M 5'primer (CCG TAT CAA CCC TTT TAG), $0.5 \mu \mathrm{M}$ 3'primer (GCT GAA AGT TGC TAT CTA G) and $0.05 \mu \mathrm{M}$ probe ([JOE]CCC CGC AGT ATA ATC AGT ATT GTA GA[NFQ-MGB]). The specific primers developed for $P$. plurivora were published by Nowakowska et al. (2016 with modification). PCR amplification included one cycle of denaturation at $95^{\circ} \mathrm{C}$ for three min, 40 cycles of $95^{\circ} \mathrm{C}$ for $30 \mathrm{sec}, 55^{\circ} \mathrm{C}$ for $30 \mathrm{sec}$ and $72^{\circ} \mathrm{C}$ for 30
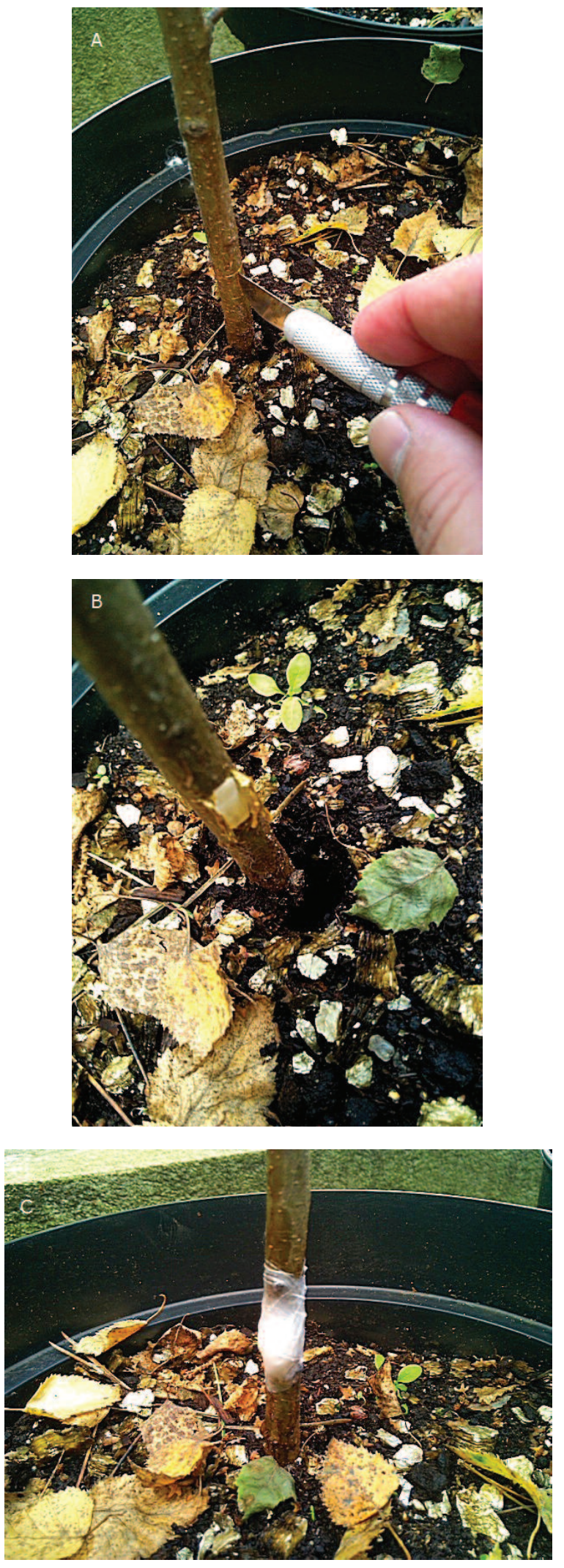

Fig. 1. Inoculation of birch seedlings with Phytophthora plurivora in 2016. A) a cut in the bark to create a wound; B) a piece of medium overgrew by $P$. plurivora put in the wound; CJ protection of the inoculation point with Parafilm. ${ }^{\circledR}$ 
Table 1. Real time PCR identification with a probe designed for $P$. plurivora. Each sample was examined twice.

\begin{tabular}{|c|c|c|c|}
\hline No. Sample & $\begin{array}{c}\text { Upper margin } \\
\text { of lesion } \\
\text { (A) }\end{array}$ & $\begin{array}{l}\text { Inoculation } \\
\text { point } \\
\text { (B) }\end{array}$ & $\begin{array}{c}\text { Lower margin } \\
\text { of lesion } \\
\text { (C) }\end{array}$ \\
\hline $\mathrm{C}_{\mathrm{T}} 1$ & 24.1 & 19.3 & 21.1 \\
\hline $\mathrm{C}_{\mathrm{T}}^{\mathrm{T}} 1^{\prime}$ & 22.5 & 19.3 & 21.8 \\
\hline $\mathrm{C}_{\mathrm{T}}^{\mathrm{T}} 2$ & 24.1 & 18.9 & 22.3 \\
\hline $\mathrm{C}_{\mathrm{T}}^{1} 2^{\prime}$ & 24.3 & 18.6 & 22.3 \\
\hline $\mathrm{C}_{\mathrm{T}}^{1} 3$ & 22.6 & 19.5 & 22.7 \\
\hline $\mathrm{C}_{\mathrm{T}}^{\mathrm{T}} 3^{\prime}$ & 21.3 & 19.4 & 23.0 \\
\hline $\mathrm{C}_{\mathrm{T}}^{1} 4$ & 18.6 & n.a. & 22.6 \\
\hline $\mathrm{C}_{\mathrm{T}}^{1} 4^{\prime}$ & 17.9 & n.a. & 21.3 \\
\hline $\mathrm{C}_{\mathrm{T}}^{1} 5$ & 22.3 & 18.1 & 21.5 \\
\hline $\mathrm{C}_{\mathrm{T}}^{1} 5^{\prime}$ & 24.4 & 17.6 & 21.0 \\
\hline $\mathrm{C}_{\mathrm{T}}^{1} 6$ & 22.2 & n.a. & 25.8 \\
\hline$C_{T}^{1} 6^{\prime}$ & 23.9 & n.a. & 25.6 \\
\hline $\mathrm{C}_{\mathrm{T}}^{1} 7$ & 22.8 & 18.0 & 20.7 \\
\hline $\mathrm{C}_{\mathrm{T}}^{1} 7^{\prime}$ & 20.7 & 19.1 & 19.8 \\
\hline $\mathrm{C}_{\mathrm{T}}^{1} 8$ & 22.9 & 21.1 & 28.2 \\
\hline $\mathrm{C}_{\mathrm{T}}^{1} 8^{\prime}$ & 22.7 & 20.5 & 27.4 \\
\hline $\mathrm{C}_{\mathrm{T}}^{1} 9$ & 20.7 & n.a. & 24.1 \\
\hline $\mathrm{C}_{\mathrm{T}}^{1} 9^{\prime}$ & 20.8 & n.a. & 22.4 \\
\hline $\mathrm{C}_{\mathrm{T}} 10$ & 22.6 & 20.0 & 24.3 \\
\hline $\mathrm{C}_{\mathrm{T}}^{1} 10^{\prime}$ & 23.3 & 19.3 & 24.0 \\
\hline
\end{tabular}

n.a. - not available

sec. Amplification was by a Step One Plus Real-Time PCR System (Applied Biosystems, USA) following manufacturer's instructions. Milli-Q water was a negative control.

A standard curve was generated using a dilution series of four different concentrations of $P$. plurivora DNA ( $5 \mathrm{ng} / \mu \mathrm{l}, 0.5$ $\mathrm{ng} / \mu \mathrm{l}, 0.05 \mathrm{ng} / \mu \mathrm{l}, 0.005 \mathrm{ng} / \mu \mathrm{l})$ in triplicate for each concentration and confirmed using the NanoDrop ND-1000 (Wilmington, USA). The $\mathrm{C}_{\mathrm{T}}$ values of the known P. plurivora DNA concentrations were determined. The $\mathrm{C}_{\mathrm{T}}$ value of each sample was then compared with the standard curve to determine the concentration of the DNA of P. plurivora present in the sample (Nowakowska et al. 2016).

In the second growing season (2017), 365 days post inoculation, 15 birch seedlings inoculated with $P$. plurivora in 2016 plus five mock-inoculated checks, were evaluated for stem necrosis and root development (Table 2).

\section{Results and Discussion}

Our findings show that silver birch is a potential host of the pathogen $P$. plurivora which developed in the cambium of artificially inoculated plants. The results also show a statistically significant difference between lesion width on stems between partial (50\%) and total (100\%) defoliation. Plants with partial defoliation showed less necrosis development, while with seedlings that were totally defoliated, the width of necrosis was significantly larger (Fig. 3). Non-inoculated plants did not show any necrosis of tissues as wounds healed quickly due to callus development. Lesions in non-defoliated and inoculated seedlings (Phy- $0 \%$ defoliation) did not differ statistically from the Phy-50\% defoliation and Phy-100\% defoliation treatments. Measurements of lesion lengths showed no statistically significant differences between controls and $50 \%$ and $100 \%$ defoliation treatments $(\mathrm{p}<0.10$;
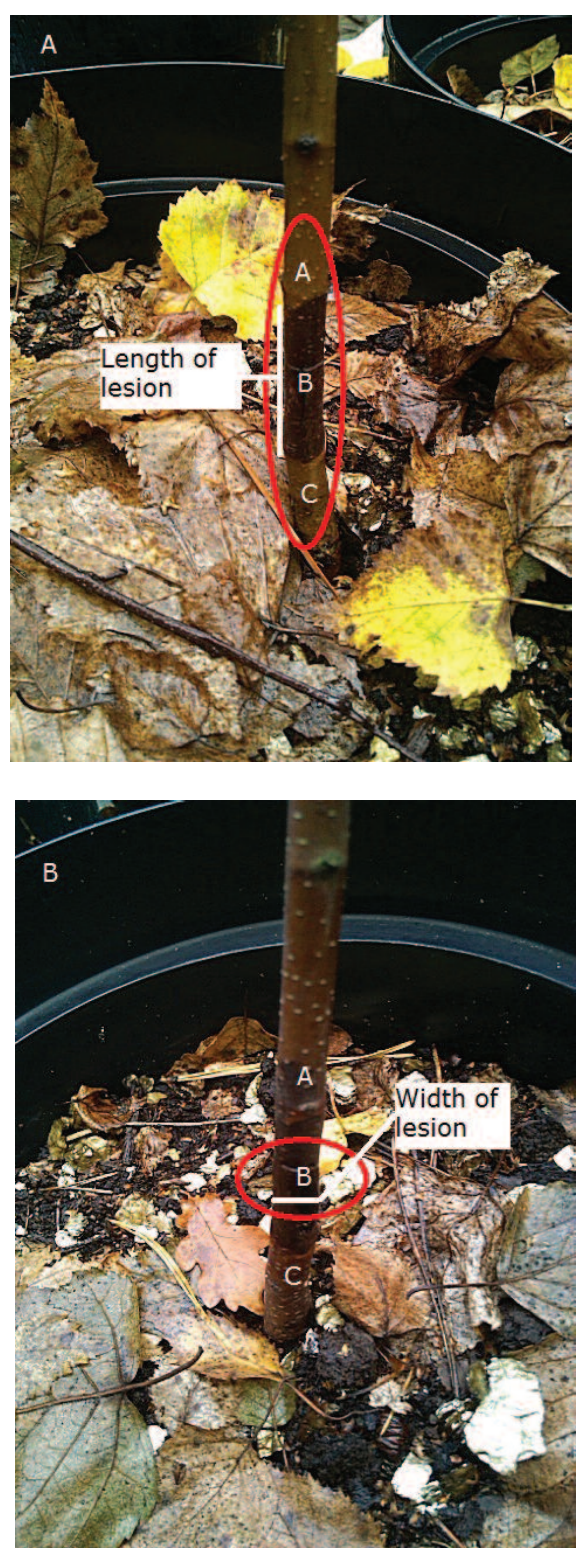

Fig. 2. Symptoms of infection on the $70^{\text {th }}$ day after birch stem inoculation, length and width of the necrosis (lesions) estimated in September 2016. Places marked with letters indicate where tissue samples were collected for real-time PCR assay to confirm the presence of $P$. plurivora.

Fig. 4). The difference between treatments possibly depends on the physiological status of the inoculated seedlings. Low physiological stress (defoliation 50\%) could induce defense reactions, while total defoliation allowed further growth of the pathogens. It is possible that seedlings that were partly defoliated had enough vigor to induce the production of secondary metabolites to suppress infection, in contrast to totally defoliated seedlings. Studies have shown that phenols (Martín et al. 2008) and other substances with antibiotic properties in leaves of host plants increased after the activity of phytophagous insects (Futuyma and Agrawal 2009). Moreover, 
Table 2. Assessment of health status of birch seedlings and necrosis development after a year (2017)

\begin{tabular}{|c|c|c|c|c|c|}
\hline Treatment & Lesion length (mm) & $\begin{array}{c}\text { Dead tissue } \\
\text { (\% of circumference) }\end{array}$ & Callus & $\begin{array}{l}\text { Root dry mass } \\
(\mathrm{g})^{\star}\end{array}$ & Dead/Alive \\
\hline Control & - & 0 & + & 75.96 & Alive \\
\hline Non-defoliated and & - & 0 & + & 54.46 & Alive \\
\hline inoculated with & - & 0 & + & 57.20 & Alive \\
\hline \multirow[t]{2}{*}{ sterile media } & - & 0 & + & 65.96 & Alive \\
\hline & - & 0 & + & 39.32 & Alive \\
\hline Average & & & & 58.58 a & \\
\hline P. plurivora & 46.58 & 98 & - & 20.75 & Alive \\
\hline \multirow[t]{4}{*}{$+0 \%$ defoliation } & 44.67 & 100 & - & 40.63 & Dead \\
\hline & 40.7 & 75 & - & 13.95 & Dead \\
\hline & 32.11 & 79 & + & 12.95 & Dead \\
\hline & 56.19 & 89 & - & 24.58 & Alive \\
\hline Average & 44.05 & 88 & & 22.57 a & \\
\hline P. plurivora & 23.15 & 71 & - & 5.38 & Dead \\
\hline \multirow{4}{*}{$+50 \%$ defoliaion } & 34.61 & 62 & - & 4.53 & Dead \\
\hline & 30.39 & 90 & - & 8.04 & Dead \\
\hline & 41.87 & 60 & - & 23.30 & Alive \\
\hline & 41.74 & 70 & + & 17.51 & Alive \\
\hline Average & 34.34 & 71 & & $11.75 \mathrm{~b}$ & \\
\hline P. plurirvora & 31.52 & 100 & - & 9.76 & Dead \\
\hline \multirow[t]{4}{*}{$+100 \%$ defoliation } & 48.25 & 68 & - & 11.70 & Dead \\
\hline & 58.68 & 69 & - & 21.48 & Dead \\
\hline & 33.3 & 52 & - & 29.13 & Alive \\
\hline & 35.67 & 69 & - & 18.29 & Dead \\
\hline Average & 41.48 & 72 & & 18.07 a & \\
\hline
\end{tabular}

* letters mean statistically significant differences between treatments according to the Kruskal-Wallis test $\mathrm{p}<0.05$

increasing the concentration of phenolic compounds in response to damage to trees is typical of how phytophagous insects can induce a defense response (Haukioja 2006). Similar reactions could be induced by pathogen infections in plant tissues (Thakur and Sohal 2013). In a different study, it was found that the total amount of nitrogen, sugars, proteins, starch, lignin and hemicellulose was lower, and phenolic compound concentration higher, in leaves defoliated in the previous year compared with leaves specifically protected from defoliation (Milanović et al. 2015). Seedlings inoculated in this experiment should be further evaluated by chromatography followed by mass spectrophotometry, which will enable us to identify the type and quantity of substances synthesized in the inoculated plants.

DNA identification of pathogens in birch plant tissues (Table 1), together with pathogen re-isolations, fulfilled Koch's postulates revealing that $P$. plurivora was present not only at the inoculation point but it also grew downwards and upwards in the stems. The $\mathrm{Ct}$ values indicate that the amount of DNA was higher at test points $\mathrm{A}$ and $\mathrm{C}$ than at the inoculation point $B$, revealing higher activity of the pathogen in the marginal zones - Fig. 2.

In the second evaluation period, 365 days post-inoculation, wounds in the control plants were covered by callus, while in the other treatments lesions of stem tissues developed further and formed blackish open cankers (Fig. 6). The lengths of lesions ranged from 23 to $58 \mathrm{~mm}$ and the circumference of dead tissues ranged from $52 \%-100 \%$. After one year, severe mortality was recorded in the combination of total defoliation with $P$. plurivora infection (Table 2). The $100 \%$ defoliation had four dead seedlings versus three in the $50 \%$ defoliation treatment and three in the non-defoliated treatment. This is greater than $50 \%$ mortality in all cases but the mortality was not assessed statistically.

The root development or lack thereof is likely a result of the defoliation applied during the treatment process. The average root biomass for control seedlings inoculated with sterile media and not defoliated was twice the root average and biomass of seedlings treated with $P$. plurivora. In the case of seedlings defoliated $50 \%$ and $100 \%$, root biomass differed significantly from the control (Table 2; Fig. 5).

However, Fig. 3 shows absolute values, while Table 2 shows the percent circumference affected. Absolute values may be less correct for different size seedlings (even as they were thoroughly selected to be homogenous for this experiment), while percent circumference can be more accurate. Table 2 shows that dead tissue averages $71 \%$ for the $50 \%$ defoliation and $72 \%$ for the $100 \%$ defoliation; both of these are less than the $88 \%$ average for the non-defoliated seedlings. This result may reflect physiological processes in birch seedlings, e.g., because of defoliation, which inhibit pathogen development in tissues. 


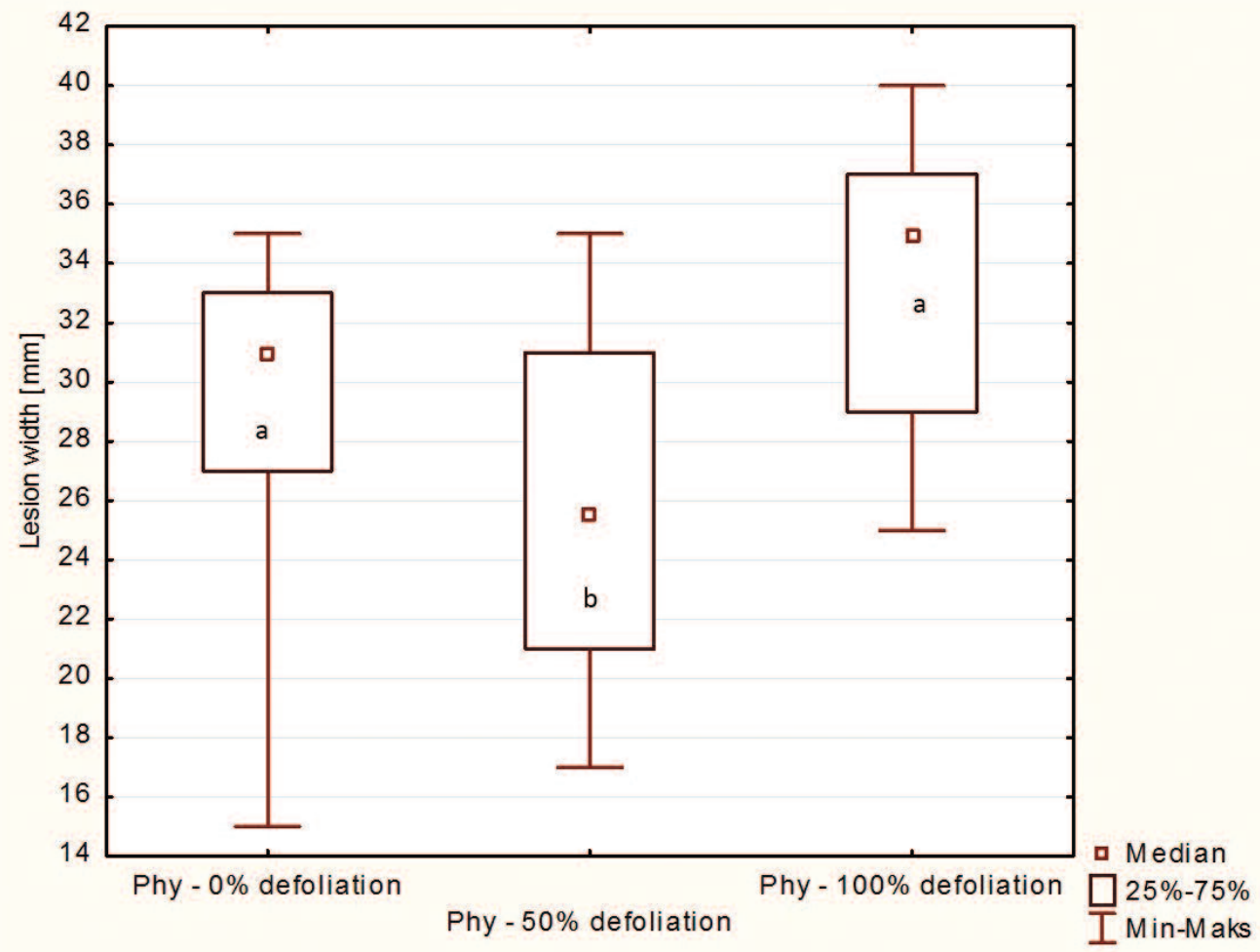

Fig. 3. Birch infections under different level of defoliation (0\% of defoliation, $50 \%$ of defoliation, $100 \%$ of defoliation). The statistically significant difference $(p$-value $=0.0201)$ on lesion width, between defoliation level was observed. Different letters indicate statistically significant differences according to the Kruskal-Wallis test at $p<0.05$.

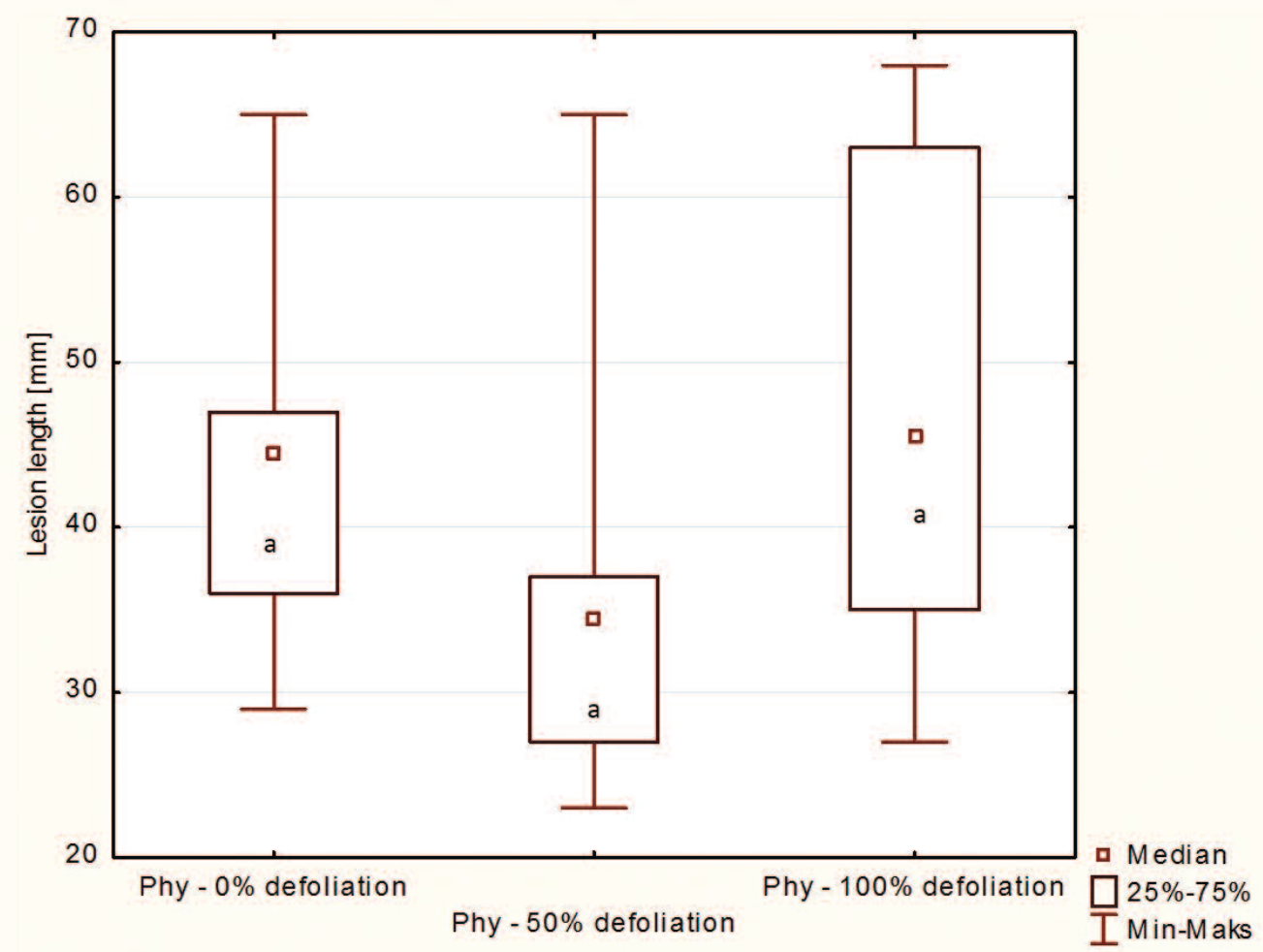

Fig. 4. Birch infections under different level of defoliation (Control - no defoliation, $50 \%$ of defoliation, $100 \%$ of defoliation). No statistically significant difference ( $p$-value $=0.1003$ ) of lesion length between defoliation level was observed. 


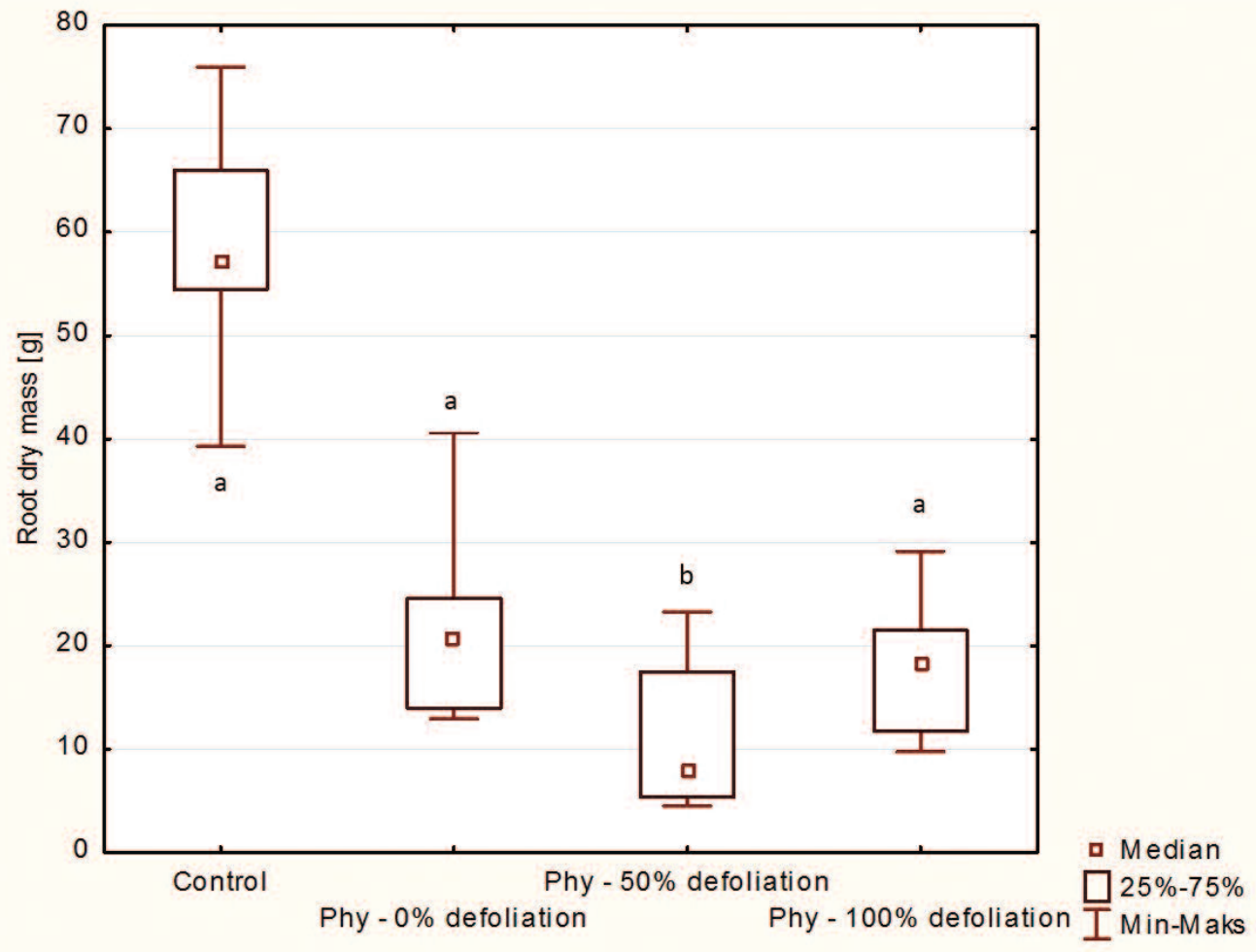

Fig. 5. Assessment of root dry mass of birch seedlings (2017).

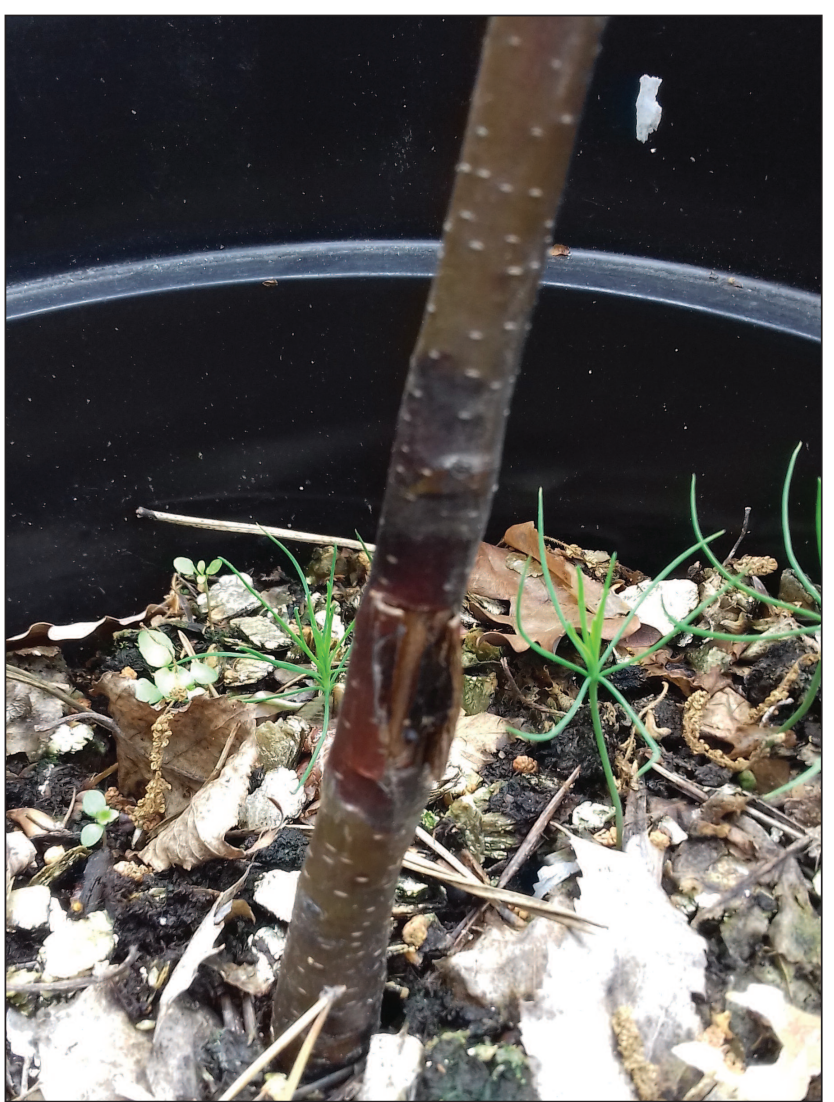

Fig. 6. Blackish necrosis of birch stem caused by $P$. plurivora a year after inoculation (in 2017).

\section{Conclusions}

- Our findings show that B. pendula is a host of the pathogen $P$. plurivora which causes significant damage to tissues, often resulting in high mortality among infected seedlings in nurseries;

- Defoliation can increase damage to birch seedlings infected by $P$. plurivora. There was a statistically significant difference in lesion size caused by $P$. plurivora after inoculation in combination with $50 \%$ and $100 \%$ defoliation. Seedlings 50\% defoliated had narrower lesions than undefoliated seedlings, and those $100 \%$ defoliated had wider lesions; and,

- The root systems of defoliated seedlings were significantly reduced.

\section{Acknowledgements}

This research was supported by the Project 240327 and a research grant from the Scholarship Fund of the Forest Research Institute (IBL) in Sękocin Stary.

\section{References}

Futuyma, D.J. and A.A. Agrawal. 2009. Macroevolution and the biological diversity of plants and herbivores. Proceedings of the National Academy of Sciences 106(43): 18054-18061. doi: 10.1073/pnas.0904106106

Haukioja, E. 2006. Tree defenses against insects. In: S. Tuzun and E. Bent (eds.). Multigenic and induced systemic resistance in plants. pp. 279-295. Springer ed., USA

Johnson, S.N., D.A. Elston and S.E. Hartley. 2003. Influence of host plant heterogeneity on the distribution of a birch aphid. Ecol. Entomol. 28(5): 533-541. doi:10.1046/j.1365-2311.2003.00547.x 
Jung, T., H. Blaschke and P. Neumann. 1996. Isolation, identification and pathogenicity of Phytophthora species from declining oak stands. Eur. J. of For. Pathol. 26: 253-272. doi:10.1111/j.1439-0329. 1996.tb00846.x

Martín J.A., A. Solla, M.R. Domingues, M.A. Coimbra and L. Gil. 2008. Exogenous phenol increase resistance of Ulmus minor to Dutch elm disease through formation of suberin-like compounds on xylem tissues. Environmental and Experimental Botany 64(1): 97-104. doi.org/10.1016/j.envexpbot.2008.05.004

Milenković, I., Keča, N., Karadžić, D., Nowakowska, J.A. Borys, M. Sikora and K. Oszako T. 2012. Folia Forestalia Polonica series A, Vol. 54 (4): 223-232.

Milanović, S., J. Lazarević, D. Karadžić, I. Milenković, L. Jankovský, A. Vuleta and A. Solla. 2015. Belowground infections of the invasive Phytophthora plurivora pathogen enhance the suitability of red oak leaves to the generalist herbivore Lymantria dispar. Ecol. Entomol. 40(4): 479-482. doi:10.1111/een.12193

Nowakowska, J.A., T. Malewski, A. Tereba and T. Oszako. 2016. Rapid diagnosis of pathogenic Phytophthora species in soil by realtime PCR. Forest Pathol. 21(1): 1-4. doi: /10.1111/efp.12303
Oszako, T. 2005. Menace of nurseries and stands (with special regards to alder) with Phytophthora species. Sylwan 149(6): 55-61.

Rytkönen, A., A. Lilja, A. Vercauteren, S. Sirkiä, P. Parikka, M. Soukainen and J. Hantula. 2012. Identity and potential pathogenicity of Phytophthora species found on symptomatic Rhododendron plants in a Finnish nursery. Can. J. Plant Pathol. 34(2): 255-267. doi:10.1080/07060661.2012.686455

Sanz, M., B. Fernandez de Simon, E. Cadahia, E. Esteruelas, A. M. Munoz, T. Hernandez, I. Estrellac and E. Pintod. 2012. LCDAD/ESI-MS/MS study of phenolic compounds in ash (Fraxinus excelsior L. and F. americana L.) heartwood. Effect of toasting intensity at cooperage. J. Mass Spectro. 47: 905-918

Thakur, M. and B.S. Sohal. 2013. Role of elicitors in inducing resistance in plants against pathogen infection: A Review. ISRN Biochemistry. 2013. Article ID 762412, 10 pages. doi:10.1155/2013/762412

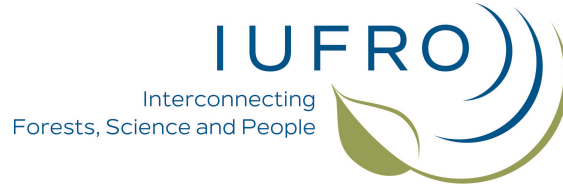

This paper is based on material that was presented at the meeting of IUFRO Working Party 7.02.02 - Foliage, Shoot and Stem Diseases, May 7-11, 2017, Niagara Falls, Ontario, Canada 